\title{
기업의 글로벌 사회적 책임(Global CSR)과 개발협력
}

\author{
김 성 규 (KOICA ODA연구실 상임연구원)
}

\section{목 차}

I. 문제의식

II. 'CSR' 의 정의와 국내외 연구동향

III. 'Global CSR' 의 정의와 범위: 개발협력과 관련하여

IV. 'CSR'과 국제기구 활동

V. 'Global CSR'의 국제적 규범

$\mathrm{VI}$. 시사점

\section{I . 문제의식}

기업의 사회적 책임(Corporate Social Responsibility, CSR)은 '기업이 경제적, 환경적, 윤 리적 책임을 다함으로써 기업의 지속가능한 성장을 유도하는 것' 으로, 이해당사자들 간의 단기 적 거래관계가 아닌 '장기적 가치 중심의 관계를 추구하는 기업전략' 으로 정의될 수 있다. 더 나아가 기업의 사회적 책임 투자(Social Responsible Investment; SRI)는 기업의 성장 전략 측면과 더불어 기업과 사회와의 상호이해, 신뢰 구축 측면에서 이해되고 있다.

한편 세계화의 진전과 함께 '기업의 글로벌 사회적 책임 (Global CSR)' 의 중요성이 강조되고 있으며 개발협력분야에서도 공공, 민간기업의 Global CSR은 핵심개념으로 자리 잡고 있다. 특 히 개도국 내 환경, 노동 조건, 근로의욕 고취, 그리고 인권 관련 기업의 사회적 책임은 더욱 강 조되고 있는 추세이다. 이러한 맥락에서 기업의 개발협력 참여는, 기업의 단기적 이윤추구 논리 
보다는 이른바 '기업의 사회적 책임(CSR)'의 수행이라는 장기적이고도 신뢰 있는 프로그램 하 에 수행되어져야 그 효과성이 나타날 수 있다고 주장된다. 또한 개발협력 과정에서 기업의 사회 적 책임은 기업에게 ‘비용' 이 아닌 ‘생산적 투자'로 기능해야 하며 이때 개발협력의 효과와 질 도 높아질 수 있으며, 개도국 내 경제적, 사회적, 환경적 책임의 수행이 곧 기업의 글로벌 성장 전략의 핵심 요소임을 인식해야 함을 강조하고 있다. 실제로 FTSE4GGood1)와 다우존스 지속 가능경영지수(Dow Jones Sustainability Index; DJSI)는 대기업의 사회적 책임투자(SRI)의 규모가 점점 커지고 그 의미가 중요해지고 있음을 단적으로 보여주고 있다(Hopkins, 2008). 이는 기업의 글로벌화가 진전되면서 개도국 내 기업이 수행하고 있는 경영실무가 윤리적, 사회 적 측면에서 평가받고 있음에서도 알 수 있다. 예를 들어 글로벌 기업들이 수원국의 노동력을 착취한다거나 현지 안전규정을 준수하지 않아 현지에서 사회문제를 야기시키는 사례가 보고되 곤 한다. 이러한 문제들을 미연에 방지하는 차원에서도 개발협력 부문에서 기업의 사회적 책임 은 간과되어서는 안 되는 중요 요소이다.

이 글은, 기업의 사회적 책임에 대한 정의와 국내외 연구 동향, 개발협력 관련 Global CSR의 범위와 내용, 기업의 사회적 책임과 관련된 국제기구 활동, Global CSR 관련 국제적 규범 등을 간략히 살펴보고, 이를 통해 개발협력부문에서 Global CSR 가지는 의미와 시사점을 도출해 보 고자 한다.

\section{II. 'CSR' 의 정의와 국내외 연구동향}

기업의 사회적 책임(CSR)은 '사회의 목표나 가치적 관점에서 바람직하다고 동의되는 정책 추구와 그를 위한 의사결정을 하는 기업의 의무 등으로 정의되며, 궁극적 목적은 기업의 지속 가능한 성장과 사회적 가치 추구라는 두 가지 요구를 모두 충족시키는 데 있다. Kotler는 CSR 을 공익캠페인, 공익연계마케팅, 사회마케팅, 사회공헌(자선)활동, 지역사회 자원봉사, 사회책 임경영 실천 영역으로 구분하고 각 영역에 대한 정의와 주요 사례를 정리했다. 이를 정리하면 아래 표와 같다.

1) 영국의 경제일간지 파이낸셜 타임스지(FT)와 런던증권거래소(LSE)가 공동으로 소유하고 있는 FTSE인터내셔널이 개발한 지수로, 2001년 7월 이래 757개의 ‘윤리적 기업’을 대상으로 환경보호, 인권보장, 사회적 책임 등의 세 가 지 항목을 조사해 우수한 점수를 얻은 기업들을 FTSE4GOOD지수에 포함시켜 발표하고 있다. 또한 담배, 무기, 핵 관련 등 3개 업종은 평가에서 원천적으로 배제되었다. 


\section{〈표 1〉 기업의 사회적 책임(CSR)의 구분과 정의}

\begin{tabular}{|c|c|c|}
\hline 구분 & 정의 & 주요사례 \\
\hline $\begin{array}{c}\text { 공익캠페인 } \\
\text { (Cause Promotion) }\end{array}$ & $\begin{array}{l}\text { 기업이 특정 사회문제에 대한 인식 } \\
\text { 제고 또는 개선을 위해 현금, 현물 } \\
\text { 또는 기업자산을 제공하는 방식 }\end{array}$ & $\begin{array}{l}\text { 미국 베엔제리(아이스크림업체) } \\
\text {; 지구 온난화 방지 캠페인 }\end{array}$ \\
\hline $\begin{array}{l}\text { 공익연계마케팅 } \\
\text { (Cause-Related } \\
\text { Marketing) }\end{array}$ & $\begin{array}{l}\text { 기업이 특정상품 판매 또는 회사 매출 } \\
\text { 의 일정금액/비율을 특정한 사회문제 } \\
\text { 개선을 위해 제공하는 방식 }\end{array}$ & $\begin{array}{l}\text { 코콤 전략 연구소: 서적 판매액 } 1 \% \\
\text { 사회복지재단 기부 }\end{array}$ \\
\hline $\begin{array}{l}\text { 사회마케팅 } \\
\text { (Corporate Social } \\
\text { Marketing) }\end{array}$ & $\begin{array}{l}\text { 공공의 건강, 안전, 환경 또는 사회복 } \\
\text { 지 개선을 목표로 기업이 행동 변화 } \\
\text { 캠페인을 개발, 실천, 지원하는 것 } \\
\text { 구성원들의 행동변화를 목적으로 한다 } \\
\text { 는 점에서 타 CSR 활동과 차이를 보 } \\
\text { 임 }\end{array}$ & $\begin{array}{l}\text { DELL 컴퓨터: 폐프린터 수거운동 } \\
\text { 맥도날드: 소아 조기 예방접종 사업 } \\
\text { P\&G사: 아기 바로 뉘어 재우기 } \\
\text { (Back to Sleep) 캠페인 }\end{array}$ \\
\hline $\begin{array}{l}\text { 사회공헌(자선)활동 } \\
\text { (Corporate } \\
\text { Philanthropy) }\end{array}$ & $\begin{array}{l}\text { 특정 사회단체나 사회문제에 기업이 } \\
\text { 현금, 현물, 특정기술, 전문지식 등을 } \\
\text { 직접 기부하는 방식 } \\
\text { 특정 사회문제나 공익사업에 직접 기 } \\
\text { 부 하는 방식 } \\
\text { 대부분 현금 기부, 물품이나 설비 등의 } \\
\text { 현물 기증, 특정 기술이나 노하우를 제 } \\
\text { 공하는 형식 }\end{array}$ & $\begin{array}{l}\text { 딜로이트 컨설팅: 사회적 기업연계 } \\
\text { 경영 노하우 및 자문제공(전문가 재 } \\
\text { 능기부 프로그램) } \\
\text { Google: 사회적 이슈 정보 실시간 } \\
\text { 제공프로그램 } \\
\text { 월트디즈니: 희귀병 아동 대상 ‘소 } \\
\text { 원들어주기' 프로그램 }\end{array}$ \\
\hline $\begin{array}{l}\text { 지역사회 자원봉사 } \\
\text { (Community } \\
\text { Volunteering) }\end{array}$ & $\begin{array}{l}\text { 지역사회의 상인들, 가맹업주, 기업 직 } \\
\text { 원들이 지역사호의 이슈에 참여하고 } \\
\text { 자원 봉사를 하도록 기업 차원에서 지 } \\
\text { 원하고 권 장하는 방식 } \\
\text { 회사차원에서는 자원봉사를 위한 유급 } \\
\text { 휴가 제공, 다양한 매칭 프로그램 등을 } \\
\text { 마련 }\end{array}$ & $\begin{array}{l}\text { 해비타트: 주택 건설 프로그램, } \\
\text { 자연보호(해안 지역 쓰레기 수거 활 } \\
\text { 동 등) 프로그램 참여 }\end{array}$ \\
\hline $\begin{array}{l}\text { 사회책임경영 실천 } \\
\text { (SR Business } \\
\text { Practice) }\end{array}$ & $\begin{array}{l}\text { 환경보호 및 사회복지 개선에 기여할 수 } \\
\text { 있는 경영 및 투자 활동(사회적 투자) } \\
\text { 기업이 가지고 있는 힘(power)을 선의 } \\
\text { 의 목적으로 이용 하는 것 }\end{array}$ & $\begin{array}{l}\text { 스타벅스: 친환경적 커피 재배 업체 } \\
\text { 와만 거래 } \\
\text { 월마트: 카본절감 업체의 제품만 } \\
\text { 납품 받기 }\end{array}$ \\
\hline
\end{tabular}

출처: Kotler, Philip(2004), Global CSR Conference(2011), Global Compact Network Korea, KMAC. 
$\mathrm{OECD}$ 는 사회적 책임을 다음의 여섯 가지 영역으로 나누어 강조하고 있는데, 첫째, 공정한 경쟁, 둘째, 법률준수, 셋째, 차별 없는 고용, 넷째, 노동권 보호, 다섯째, 환경보호, 여섯째, 기 업시민권이 그것이다. 그런데 사회적 책임의 효과성에 대한 평가는 엇갈리며 논쟁적이다. 긍정 적인 평가로는 첫째, 기업의 사회적 책임의 수행은 해당 기업의 이미지를 보호·향상시키며, 둘 째, 경영자가 윤리적 행동에 대한 관심을 높이며, 셋째, 이해관계자들 간 신뢰를 높이며, 넷째, 기업의 사회적 책임의 수행은 발생한 위기에 대응하기보다는 위기를 사전에 예방하는 효과를 가지며, 다섯째, 기업 경영의 투명성을 강제할 수 있다는 점 등을 들 수 있다. 반면 부정적인 평 가는, 첫째, 기업의 사회적 책임 강조는 생산성을 저해하며 둘째, 사회적 책임 관련 규범과 윤리 강령의 강조는 기업에게 부가가치 없는 비용증가만을 가져 온다는 견해이다(이종서 2010: 212-213). 결국 이러한 평가에 대한 유의성 판단은 사례연구를 통해 이루어질 수 있을 것이다.

기업의 사회적 책임에 대한 국내외 연구 동향을 간략히 보면, 주로 '기업의 사회적 책임의 특 성과 그 효과' 를 분석하고 있음을 알 수 있다. Pava 'Krausz(1996) 그리고 Stanwick(1998) 등은 기업을 대상으로 한 실증연구를 통해 CSR과 재무성과간의 긍정적인 연관성이 있음을 밝 혀냈다. 한편 Brown · Dacin(1997)은 CSR이 기업과 기업이 생산해 내는 제품 브랜드 평가에 크게 영향을 미친다는 것을 보여주었다. 더 나아가 Bhattacharya(2008), Korschun(2011) 등 에 따르면 CSR은 '기업과 소비자 간의 관계를 향상시킬 수 있는 중요자산' 이라고 정의하기도 했다. 국내에서는 이종서(2010)의 '기업의 사회적 책임(CSR)과 EU국가의 도시 간 · 부문별 협 력정책과의 연관성에 대해 연구' 가 주목받는데, 그는 기업의 사회적 책임의 개념을 '사회공헌' 이나 ‘투명경영' 등 협의적인 개념으로 접근하는 것을 지양하고, 사회적 책임의 수행 배경을 장 기적이고도 가치 중심적인 기업전략으로 파악했다. 이러한 논의에 따르면 기업이 사회적 책임 을 수행하는데 드는 비용은 투자로 인식되어야 하며 이를 통해 기업경쟁력 강화도 이루어질 수 있다는 분석이다. 실제로 $\mathrm{EU}$ 국가에서는 열린 단일시장의 출현에 발맞추어 기업의 사회적 책임 이 정책적으로 더욱 엄격히 규정되고 규범화되고 있는 상황이다. 이러한 유럽 사례가 다국적 기 업의 개도국에서 사회적 책임에 대한 논의에 시사하는 바가 크다. 즉, 개도국 사회, 문화적 특성 을 고려하면서도 글로벌 기준에 준하는 사회적 책임의 지표개발하고 이를 확대 적용해 나가는 것이 필요하다.

한편 2000년대 중반 미국기업의 기업 윤리문제가 대두되고 기업파산이 상황에 직면하면서, 미국 기업과 학계는 CSR을 기업의 지속가능성(corporate sustainability)문제와 접목시켜야 만 하는 전략적 개념으로 이해하기 시작했다는데 주목할 필요가 있다. 변선영 · 김진욱(2011)은 CSR을 '전통적 CSR' 과 '전략적 CSR(Strategic Corporate Social Responsibility)2'로 구 
분하고 전략적 $\mathrm{CSR}$ 활동이 전통적 $\mathrm{CSR}$ 활동보다 기업성과에 더 큰 긍정적 영향을 미치는지, 더 나아가 기업 재무성과 향상에 매개효과를 갖는지 알아보고자 했다. 이를 위해 한국과 일본의 제조 기업을 선정하여 비교분석을 실시했는데, 연구결과 전략적 CSR활동이 기업의 사회적, 재 무적 성과 영역 모두에서 전통적 $\mathrm{CSR}$ 활동보다 더 크고 긍정적인 영향을 주는 것으로 나타났 다. 또한 전략적 $\mathrm{CSR}$ 활동이 기업의 이익창출, 사회공헌, 사회혁신의 책임활동 등에도 매개효 과를 갖는 것으로 확인되었다. 이는 기업이 CSR을 기업의 홍보이미지 제고를 위한 비용정도로 간주하던 이전 경향에서 벗어나 이제는 '전략적 투자활동' 으로 간주해야 함을 의미한다. 이들 비교분석의 가설은 Poter and Kramer(2006)의 연구에 바탕을 두는데, Poter and Kramer 는 '경쟁우위와 CSR' 이라는 연구를 통해 '전략적 CSR은 단기적 소모비용이 아닌 기업의 장 기적인 기회, 혁신, 경쟁우위의 원천 자원' 이라고 강조 한다.

\section{III. 'Global CSR' 의 정의와 범위: 개발협력과 관련하여}

세계화(Globalization)를 바탕으로 기업 활동의 국경이 없어지고 그 활동과 영향이 주권국 가의 영역을 넘나들게 되었다. 이에 종래 국가 영역에서 발전되어 왔던 기업의 사회적 책임 (CSR)은 패러다임의 전환을 맞이하게 되었으며, 다국적 및 글로벌 기업의 진출국가 내에서의 사회적 책임 문제가 대두되었다. 이러한 맥락에서 전 지구적인 차원에서 '기업의 글로벌 사회적 책임(Global CSR)' 에 대한 관심이 높아지고 있으며, 세계경제환경에서 Global CSR의 추구는 국제기구와 공공, 민간 기업 모두에게 하나의 중요한 경향이 되고 있다.

그런데, Global CSR은 수원국 현지의 문화와 관습, 전통, 사회적 배경, 소비자의 인식 등에 부합해야 되며 기업전략은 해당 국가의 시장과 친화적으로 설계되어야 함을 강조하고 있다. 기 업의 해외 경영에서 전통적 전략 외 진출국 사회와의 상호작용, 즉 기업의 사회적 책임에 대한 전략적 고려가 경영의 필수 사항으로 부각되고 있는 것이다. 왜냐하면 현지국 사회와 소비자로 부터 기업이 신뢰를 확보하는 것은 결코 용이한 일이 아니며, 특히 저개발 국가를 위한 비즈니 스 창출가능성을 고려할 때는 더욱 그러하다. 예를 들어 개도국의 '빈곤을 이용' 하는 비즈니스

2) SCSR(Strategic Corporate Social Responsibility)은 2001년 Porter and Kramer에 의해 분석 개념으로 제시 된 후 최근 사회적 기업 연구 영역에서 큰 관심을 받고 있는 개념인데, '기존의 전통적 CSR을 기업의 지속가능성 이나 경쟁우위를 확보하기 위한 자원으로 보다 적극적으로 활용하는 활동' 으로 정의할 수 있다. 
가 아닌 ‘빈곤의 비즈니스’ 창출하기 위해 CSR은 기본 요소이며, 이때 CSR 활동을 경영의 부 가적인 활동이 아닌 '경영활동 자체’ 로 보는 관점의 전환이 요구된다.

한편 기업의 글로벌 사회적 책임(Global CSR)을 경영적인 관점이 아닌 개발협력 관점에서 바라볼 수 있다. 이를 위해 첫째, 개발협력과정에서 Global CSR이 중요한 이유는 무엇인지, 둘 째, 개발협력에 참여하는 기업에게 요구되는 Global CSR의 범위는 어디까지인지에 대해 질문 할 필요가 있다. 개발협력 과정에서 기업의 글로벌 사회적 책임은 경제적 책임, 사회적 책임, 환 경적 책임 등 세 가지 요소를 가지며, 이것이 개발 협력 과정에서 기업의 지속적 성장을 가능하 게 하는 핵심요소라고 판단된다. 흔히 $3 \mathrm{P}$ 라고 일컬어지는데, 경제적 책임은 이윤(Profit)의 발 생을 의미하며, 사회적 책임은 수원국 국민(People)에 대한 책임, 그리고 환경적 책임은 전 지 구적(Planet) 차원에서의 환경 의식을 의미한다. 개발협력과정에서 기업의 사회적 책임이 중요 한 이유는 이러한 가치 개발이 개발협력의 효율과 효과성에 긍정적인 영향을 미친다는 점이다.

기업의 글로벌 사회적 책임 범위는 통상 경제적 책임, 법적 책임, 윤리적 책임, 자선적 책임 등 네 가지로 나눌 수 있다. 각 범위의 내용과 개발협력에서 범위들 간 관계성과 의미를 살펴보 면 다음과 같다.

\section{〈그림 1〉 기업의 글로벌 CSR 범위}

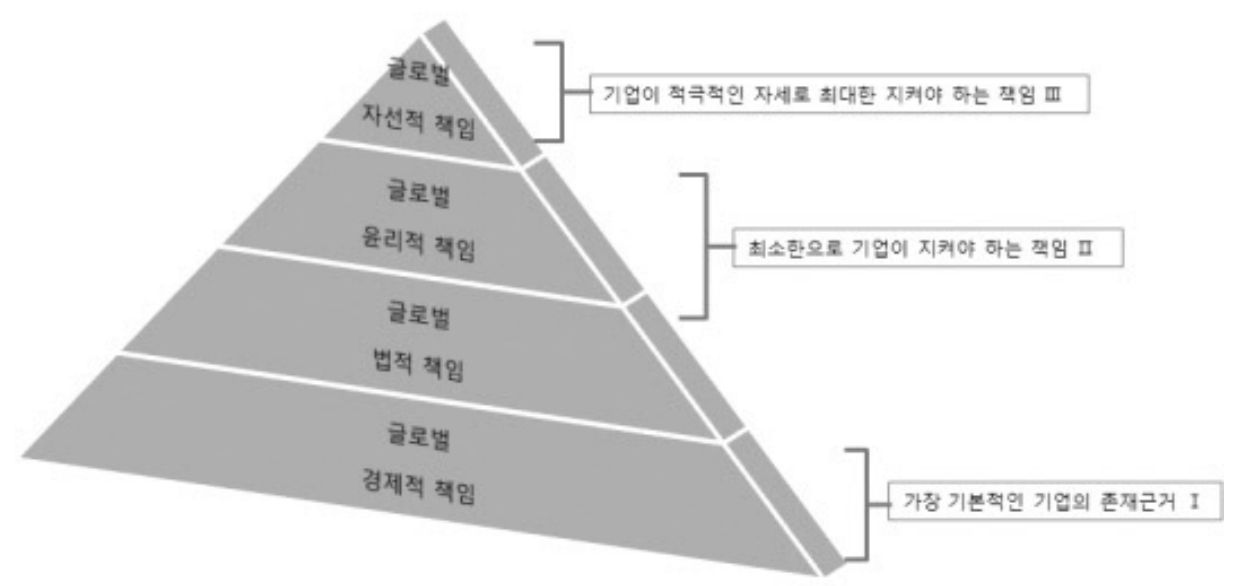

출처: 홍성현, 2010: 51 , 재구성

글로벌 경제적 책임은 기업의 가장 기본적인 존재 근거로, 기업이 불필요한 비용을 최소화하 고 수익을 최대화하는 등의 방법을 통해 이익을 발생하게 하는 것, 즉 이익의 최적화를 이루어 
내는 것을 의미한다. 그런데 여기서 비용의 최소화가 곧 '생산적 투자' 의 축소를 의미하지 않는 다. 오히려 여기서 말하는 경제적 책임이란 높은 품질의 제품과 서비스 제공, 현지 소비자의 욕 구 충족, 그리고 더 나아가 괜찮은 일자리(decent work) 창출을 위한 책임을 의미한다. 글로벌 법적 수준은 기업이 개발협력 과정에서 국제법을 준수하고 환경이나 소비자에 대한 규정을 지 키는 것을 의미한다. 이는 준수하지 않으면 처벌을 받는 강제적 책임인데, 예를 들면 해외 진출 기업은 현지 시장을 교란시킬 수 있는 덤핑행위, 부당경쟁 행위, 현지 정부나 관료에게 뇌물을 공여하는 행위, 노동활동을 탄압하는 행위, 수원국 환경을 오염시키는 행위 등을 하지 말아야 할 법적 의무가 있다. 글로벌 윤리적 책임은 법적으로 정해진 최소한의 기준 이상으로 의무를 다하는 것이다. 여기에는 환경보호, 인권존중, 아동노동착취 금지, 상호신뢰, 투명한 거래 등이 포함된다. 글로벌 법적 책임과 윤리적 책임은 개발협력과정에서 기업이 최소한으로 지켜야 하 는 책임이라고 규정될 수 있다. 마지막으로 글로벌 자선적 책임은 수원국 지역 및 사회에 대한 자발적 기부활동을 의미한다. 예를 들면 빈곤층 및 소외계층 지원, 장학재단설립 및 지원, 지역 사회 공헌 프로그램, 의료지원 등 각종 지역 사회 봉사활동 등이 그것이다. 자선적 책임은 기업 이 반드시 지켜야할 책임은 아니지만 기업이 적극적인 자세로 최대한 지켜야 하는 책임으로 분 류할 수 있다. 기업이 개발협력 과정에 참여할 때는 〈그림 1>에서 나타내고 있는 III 수준의 책임 이 특히 요구된다. 한편 임정성(2009)은 기업의 사회적 책임이 자선을 넘어 사업전략으로 자리 잡아야 됨을 강조하면서, 지역에 따라 자선활동 보다도 기업의 법적, 윤리적 규범 준수에 더 관 심을 가져야 할 필요성을 언급하기도 한다. 이는 자선적 규범 준수가 법적, 윤리적 규범 준수의 바탕 하에서만 의미를 가질 수 있다는 점을 아울러 지적한 것이다.

\section{IV. 'CSR'과 국제기구 활동}

$\mathrm{UN}, \mathrm{OECD}$ 그리고 세계은행 등은 기업의 사회적 책임 분야에서 다양한 논의와 활동을 전개 시켜오고 있다. 세계은행의 2002, 2004년 보고서 '기업의 사회적 책임 강화에 있어 공공무문 의 역할(public sector roles in strengthening social responsibility)' 과 2005년 보고서 '공공부문의 사회적 책임(Social Accountability in the Public Sector)' 등이 주목할 만하 다. 특히 2002년 보고서는 개도국 내에서 기업의 사회적 책임과 역할 강화를 위한 다섯 가지 주 요의제를 제시하고 있는데, 첫째, 기업의 사회적 책임이라는 의제가 강조되게 된 배경, 주요 수 행 주체, 효과적인 수행방식 그리고 기업의 사회적 책임관련 주제가 국제 투자에 미치는 영향, 특히 개도국 투자에 미치는 영향 분석의 필요성, 둘째, 개도국 정부와 공기업이 사회적 책임과 
관련된 표준설정(standards-setting)에 일정 역할을 하며 참여해야할 필요성, 셋째, 기업의 사회적 책임과 관련된 투자를 촉진시키기 위한 안정적이고 투명한 환경 조성의 중요성, 넷째, 민간 기업이 개도국 공공정책 과정에 직접적이고 보다 광범위하게 참여하도록 유도해야 하며, 다섯째, 기업의 사회책임과 관련 지역적 또는 국가적 우선순위와 개발전략을 위한 틀 (framework)을 개발해야 할 필요성(Fox, Ward and Howard 2002: 25-26)을 강조하고 있 다. 한편 세계은행 그룹의 국제금융공사(IFC)의 '외국인투자 자문서비스(FIAS)'는 2007년 기 업의 사회적 책임관행(Corporate Social Responsibility Practice)이라는 프로그램을 통해 개도국 정부가 기업의 사회적 책임 유도를 위해 사용할 수 있는 정책 수단에 대해 조언한다. 프 로그램은 첫째, 지역사회 이해관계자 참여 프로그램, 둘째, 지속가능성 전략과 의사소통 프로그 램, 셋째, 노동관행과 인권프로그램 등의 세 영역으로 구분된다.

UN은 기업의 '지속가능발전(sustainable development)3)' 이란 개념을 발전시키면서 기업 의 사회적 책임 관련 규범을 설정해 왔다. 초기에는 주로 공기업의 역할을 중심으로 논의가 진 행되어 왔으나 90 년대 들어 민간 기업을 포함한 다양한 사회부분의 참여와 기여의 중요성을 언 급하면서 기업의 사회적 책임도 결국 기업의 지속가능한 발전에 기여한다는 관점을 견지하고 있다.

$\mathrm{OECD}$ 는 이미 70년대 중반 이후 다국적 기업의 CSR 관련 규범을 채택, 발전시켜왔다. 1976 년 '국제투자와 다국적 기업에 관한 OECD 선언(OECD Declaration on international Investment and Multinational Enterprises)' 을 통해 '다국적 기업 가이드라인' 이라는 규 범을 채택하면서 정보공개의무, 고용 및 노사관계, 환경문제, 뇌물, 조세 등의 분야에서 다국적 기업의 사회적 책임을 규정했다.

3) 지속가능발전 개념은 자연과 천연자원보전을 위한 국제연합(IUCN)이 UN 환경프로그램, 세계야생기금(WWF)의 도 움을 받아 1980년에 발표하고 UN총회가 채택한 세계환경보전전략에서 시작되었다. 이후 1987년 '환경과 개발에 관한 세계위원회 보고서-인류 공통의 미래' 보고서는 지속 가능발전을 '미래세대의 욕구 충족 능력을 희생시키지 않으면서 현 세대의 욕구를 충족시키는 발전'으로 규정했다. 


\section{V. 'Global CSR'의 국제적 규범}

2000년대 중반 이후 UN과 NGO 등은 CSR 관련 표준지침을 설정하면서 기업의 경영적, 사 회적 책임에 대한 국제적 규범을 제시하기 시작했다. 대표적인 기준으로 Global Compact 10 대 원칙, Global Reporting Initiative, ISO26000 등을 꼽을 수 있다.

Global Compact는 UN 사무총장 코피 아난의 제안으로 2000년 출범한 자발적 이니셔티브 네트워크 조직으로 ‘인간의 얼굴을 한 자본주의' 를 실현하기 위해서는 무엇보다 기업의 역할이 중요하다는 문제의식에서 출발했다. 주로 인권, 노동, 환경, 반부패 부문등과 관련된 10 대 원칙 을 제시하고 있다. 조직의 핵심은 Global Compact 사무국과 6개 UN기관이며, 관련정부, 기 업, 노동계, 시민단체 등 모든 이해관계자들에게 조직을 개방하고 있다.

\section{〈표 2〉 Global Compact 10대 원칙}

\begin{tabular}{|c|c|}
\hline 부 분 & 원 칙 \\
\hline 인권 & $\begin{array}{l}\text { 1. 기업은 국제적으로 선언된 인권의 보호를 지지하여야 한다. } \\
\text { 2. 기업은 인권침해에 가담하지 않아야 한다. }\end{array}$ \\
\hline 노동 & $\begin{array}{l}\text { 3. 기업은 결사의 자유와 단체교섭권의 권리를 보장해야 한다. } \\
\text { (결사의 자유에 관한 ILO협약 제87호 및 제 } 98 \text { 호) } \\
\text { 4. 기업은 모든 형태의 강제노동을 배제하여야 한다. } \\
\text { (강제노동금지에 관한 ILO협약 제 } 29 \text { 호 및 제 } 105 \text { 호) } \\
\text { 5. 기업은 아동노동을 효과적으로 폐지하여야 한다. } \\
\text { (아동노동철폐에 관한 ILO협약 제 } 138 \text { 호 및 제 } 182 \text { 호) } \\
\text { 6. 기업은 고용 및 업무에서 차별을 배제하여야 한다. } \\
\text { (차별금지에 관한 ILO협약 제 } 100 \text { 호 및 제111호) }\end{array}$ \\
\hline \multirow[t]{2}{*}{ 환경 } & $\begin{array}{l}\text { 7. 기업은 환경문제에 대한 예방적 접근을 지지하여야 한다. } \\
\text { 8. 기업은 환경에 대한 책임 강화에 솔선하여야 한다. }\end{array}$ \\
\hline & 9. 기업은 환경 친화적인 기술개발 및 보급을 지원하여야 한다. \\
\hline 반부패 & 10. 기업은 부당가격 청구 및 뇌물 등의 부패에 대응하여야 한다. \\
\hline
\end{tabular}

출처: http://www.unglobalcompact.org 
Global Reporting Initiative(GRI) 는 1997년 창설된 기구로, 기업의 글로벌 경영지속가능 성 관점에서 성과지표를 제시하고 이를 지속적으로 개정해 오고 있다. 성과지표는 경제, 환경, 노동관행과 좋은 일자리, 인권, 사회, 제품책임 등의 범주로 나누어 제시되고 있으며, 각 범주의 관점들을 설정하고 있다. 기업은 해당 가이드라인에 따른 보고서를 작성하여 공개할 수 있으며 한국은 한국전력, 삼성 $\mathrm{SDI}$, 현대자동차 등 12 개 기업이 GRI에 보고서를 등록, 공개하고 있다.

\section{〈표 3〉 GRI 지속가능성 보고 기준의 성과지표}

\begin{tabular}{c|c|c}
\hline 구분 & 범주 & \multicolumn{1}{c}{ 관점 } \\
\hline 경제 & 경제영향 & 고객, 협력업체, 직원, 자본, 공공부문 \\
\hline 환경 & 환경 & $\begin{array}{l}\text { 에너지, 물, 생명다양성, 배출, 폐수, 폐기물, 제품과 } \\
\text { 서비스, 법규준수, 운송 }\end{array}$ \\
\hline \multirow{2}{*}{ 사회 } & $\begin{array}{c}\text { 노동관행 } \\
\text { 좋은 일자리 }\end{array}$ & 고용, 노사관계, 보건/안전, 교육/훈련, 다양성과 기회 \\
\hline & 인권 & $\begin{array}{l}\text { 차별금지, 결사와 단체협상의 자유, 아동노동, 강제노동, } \\
\text { 징계관행, 보안관행 }\end{array}$ \\
\hline & 사회 & 지역사회, 뇌물과 부패, 경쟁과 가격정책 \\
& 제품책임 & $\begin{array}{l}\text { 고객 보건과 안전, 제품의 질과 서비스, 광고, } \\
\text { 프라이버시 존중 }\end{array}$ \\
\hline
\end{tabular}

출처: http://www.globalreporting.org

한편, ISO 26000은 CSR에서 C(Corporate)를 삭제하여 기업 이외에 정부, 노조, 시민단체 등에게도 적용할 수 있는 보다 광범위한 '사회적 책임 가이드라인(Guidance on Social Responsibility)' 설정 노력이라는 의미를 지닌다. 이는 사회적 책임이라는 개념 설정과 기업을 포함 한 개발협력 관련 조직이 다루어야 할 사회적 책임 관련 사업에 대한 국제적인 합의와 실 행지침을 마련했다는 점에서 주목된다. 2005년 9월 회의에서 ISO 26000 8개항에 합의했다. 


\section{〈표 4〉ISO 26000 의 주요 내용}

\begin{tabular}{c|l}
\hline \multicolumn{1}{c|}{ 명칭 } & \multicolumn{1}{c}{ ISO 26000 Guidance on Social Responsibility } \\
\hline 적용범위 & 기업, 정부, 노조, 시민단체 등의 사회적 책임에 대한 지침 \\
\hline \multirow{3}{*}{ SR 원칙 } & $\begin{array}{l}\text { 국제법과 관련 지침을 존중 } \\
\text { 조직의 유연성 및 자주성 존중 } \\
\text { 각국의 문화 경제적 차이 존중 } \\
\text { 투명성, 공정성, 신뢰성, 적합성 등 } \\
\text { 관계자 신뢰와 만족을 통해 지속적 사업의 연속성 }\end{array}$ \\
\hline SR 체계 구축 & $\begin{array}{l}\text { 조직의 비전, 목적, 정책, 전략 및 SR 이행 간의 관계 } \\
\text { SR 정책 및 의무, 조직관리, 자원배정, 커뮤니케이션 정책 }\end{array}$ \\
\hline 조직내 SR관리 & $\begin{array}{l}\text { 이해관계자 참여 } \\
\text { SR 이슈 규명, SR 이슈 분석 및 평가 } \\
\text { 이행, 성과 및 이행 감시, 유지 및 개선 }\end{array}$ \\
\hline SR 커뮤니케이션 & $\begin{array}{l}\text { 이해당사자와의 커뮤니케이션 원칙 및 절차 등 시스템 } \\
\text { 성과 홍보 도구로서의 보고 }\end{array}$ \\
\hline
\end{tabular}

출처: 이장원 2006: 23

개도국의 많은 사회적 이해당사자들도 ISO 26000을 통해 개도국 내 다국적 기업의 지나친 경쟁으로 인해 발생할 수 있는 사회적 문제들을 해소하거나 예방할 수 있는 기준을 설정할 수 있다는 점에서 환영하고 있다. 즉, ISO의 SR작업반에는 기업만이 아니고 정부, 노조, 소비자대 표, $\mathrm{NGO}$ 단체, 기타 전문가들이 이른바 관련 이해당사자(stakeholder) 자격으로 동등하게 참 여하고 있으므로 선진국과 개도국들의 여러 이해당사자들의 입장을 종합하면 결국 기업의 사회 적 책임이 만들어 질 수밖에 없다(이장원 2007:44)는 논리이다.

이상의 글로벌 CSR 관련 국제기구 평가지표의 핵심 내용을 간략히 비교, 요약해 보면, Global Compact는 인권, 노동조건, 환경 등 기업의 투명성과 사회적 책임을 강조하며, GRI 가이드라인은 기업의 지속가능성을 평가의 주요 내용으로, ISO 26000은 기업, 정부, 노조, 시 민단체 등 모든 조직에 적용될 수 있는 사회책임 경영 가이드라인을 제시하고자 한다. 그런데 이러한 국제기구 평가지표적용이 개발협력에 참여하는 기업의 경쟁력과 어떠한 연관성을 갖는 지, 그리고 개발협력에 참여하는 기업에게 보다 엄격한 규범의 적용과 평가가 진행되어야 한다 는 점을 이해 당사자들이 동의하고 있는지를 실증적으로 검증해 내는 작업은 필요하다. 


\section{〈표 5〉글로벌 CSR 관련 국제기구 평가지표}

\begin{tabular}{c|l|c}
\hline 지표 & \multicolumn{1}{|c}{ 내용 } & 평가기관 \\
\hline Global Compact & $\begin{array}{l}\text { 기업의 투명성과 사회적 책임을 강조 } \\
\text { 인권, 노동, 환경 등 10 대 원칙 제시 }\end{array}$ & UN \\
\hline $\begin{array}{c}\text { GRI(Global Reproting } \\
\text { Initiative) }\end{array}$ & $\begin{array}{l}\text { 지속가능성보고기준(Sustainability Reporting Guidelines): } \\
\text { 기업의 경제, 환경, 사회분야의 성과에 대한 보고프레임워크로 } \\
\text { 서 기업의 지속가능성 보고 가이드라인 }\end{array}$ & UN \\
\hline ISO 26000 & $\begin{array}{l}\text { 사회책임경영가이드라인: 기업, 정부, 노조, 시민단체 등 모든 } \\
\text { 조직에 적용될 수 있는 사회적 책임(SR: Social } \\
\text { Responsibility)에 대한 지침 }\end{array}$ & ISO \\
\hline
\end{tabular}

출처: 이종서, 2010: 217

따라서 향후 연구과제로는 첫째, UN, 영국의 ETI(Ethical Trading Initiative), OECD, ILO, 국제표준화기구(ISO) 등 'Global CSR'에 대한 국제기구 평가지표인 Global Compact, ETI Base Code, GRI(Global Reporting Initiative) 가이드라인, ISO26000 등 지표 자체에 대한 연구와 둘째, 이러한 평가지표가 실제 개발협력과정에서 어떻게 적용되고 있는지에 대한 사례연구가 필요하다. 예를 들어 브리티시석유, 코카콜라, 모토롤라, 네슬레 등의 개도국에 활 발하게 진출하고 있는 기업들의 현지국내 CSR 적용사례를 평가할 수 있다. 셋째, 이러한 사례 연구는 민간기업의 효과적인 개발협력 참여 확대 방안과 개발협력 효과성 제고의 틀을 제시하 는데 기여할 수 있다. 넷째, 한국 민간기업의 Global CSR 전략 수립과 개발 효과성 제고의 관 점에서 민간기업의 개발협력 참여 확대 방안을 모색해 볼 수 있다.

\section{VI. 시사점}

이상의 논의를 통해, Global CSR과 개발협력 관련 몇 가지 시사점을 정리해 볼 수 있다. 첫 째, Global CSR은 단순한 경영전략에 머무는 것이 아닌, 기업의 발전과 불가분의 관계를 가지 는 규범이다. 자발적이든 의무조항이든 기업의 사회적 책임의 준수는 성공적인 기업 활동에 필 수요소라는 점이다. 둘째, 개발협력과정에서의 기업의 사회적 책임은 곧 기업 가치를 높이는 것 이라는 인식이 중요하다. 이를 위해 현재 UN을 중심으로 이루어지고 있는 사회책임투자(SRI), 
ISO 26000 등이 국제표준으로 정착되어야 하며, Global CSR 기준의 준수가 개발협력의 효과 성으로 나타나며 이는 곧 기업의 성공전략으로 자리 잡는 선순환 구조를 지향해야 한다. 셋째, Global CSR 인증에 대한 범사회적 동의를 구축해야 한다. 국제기준은 무엇보다 이해당사자들 이 모두 동의하는 인증기준이 되어야 하며, 이러한 전제 하에 인증 기준 적용은 보다 의무적으 로 다루어져야 한다. Global CSR 인증 기준적용 강화에 대한 동의는 결국 건실한 민간기업의 개발협력 참여확대와 개발협력의 질을 제고할 수 있다. 예를 들어 개발협력 과정에서의 CSR 관 련 규범의 확대 강화, 적용은 비용의 증가와 위험의 확대가 아닌 기업의 장기적인 발전과 개발 협력 사업의 효과성을 동시에 획득할 수 있는 기제이다. 넷째, 개발협력과정에서 현지 진출 기 업은 수원국 내에 형성된 다양한 지역 거버넌스, 정부를 포함한 관련 이해당사자들과의 합리적 의사소통을 통한 신뢰관계형성에 보다 힘써야 한다. 이러한 맥락에서 기업의 사회적 책임이 단 순한 사회공헌 지수로 환원되기보다는 현지 개도국 지역 커뮤니티와 소통, 그리고 그 과정에서 형성된 파트너십의 구축노력으로 이해될 필요가 있다. 결국 기업은 CSR을 통해 개도국의 다양 한 이해관계자들과 상호간 더 많은 이해를 증진시킬 수 있으며, 이를 통해 현지 환경에 대한 보 다 적합하고 유연한 대응을 하는 등 기업 경쟁력 강화를 모색할 수 있다. 다섯째, 기업의 사회적 책임 관련 국제기구, $\mathrm{NGO}$, 원조기구 등은 개발협력 관점에서 기업의 글로벌 사회적 책임 이행 의 모범사례, 즉 Global CSR의 국제 규범 준수를 통한 개발협력 성공사례를 발굴하고 이를 홍 보, 전파하는 데 노력을 기울여야 한다. 


\section{참고문헌}

\section{1. 국내문헌}

노한균(2008), 기업의 사회적 책임에 관한 국제 동향: 국제기구 논의를 중심으로, 한국비영리연구 제6권 제 3 호.

변선영 · 김진욱(2011), 한 일기업의 전략적 CSR 활동과 기업성과, 국제경영연구, 제 22 권, 제 1 호. 신상현(2008), 글로벌 기업의 사회적 책임 실현, 경영계 7,8월호.

이장원(2006), 노동 - 사회측면에서 진단한 CSR의 실태와 발전방향, 노동리뷰 통권 제 24 호, pp.20-39, 한국노동연구원

이장원(2007), 기업의 사회적 책임(CSR)의 노동관련 국제동향과 시사점, 노동리뷰 통권 제 32 호, pp.35-47, 한국노동연구원

이종서(2010), 유럽연합과 기업의 사회적 책임(CSR): 현황과 전망, 국제지역연구 제 14 권 제 1 호.

임정성(2009), 인도CSR, 자선 넘어 사업전략으로, Chindia Journal, 2월호.

장홍근, 김성규 외(2011), 사회적 기업과 인적자원 전략, KLI 연구보고서.

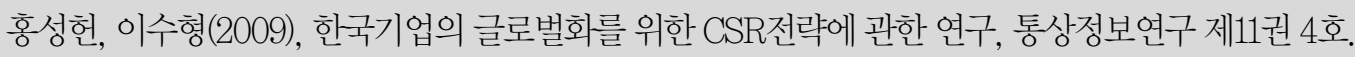

홍성헌(2010), 지속가능경영을 위한 글로벌 CSR전략 및 실천방안, “임금연구” 가을호.

\section{2. 국외문헌}

GRI(2006), Sustainability Reporting Guidelines 2000-2006, 한국어판

Bhattacharya, C.B.(2008), 'Using Corporate Social Responsibility to Win the War for Talent', MIT Sloan Management Review, vol.49, no.2.

Brown, T.J. and Dacin(1997), P.A., 'The company and the product: corporate associations and consumer product responses', Journal of Marketing, vol. 61, no.1.

BSI(2010), Guidance on Social responsibility, BS ISO 26000, BSI Standards Publication. 
Fox, Tom, Ward, Halina and Howard, Bruce(2002), Public Sector Roles in Strengthening Corporate Social Responsibility: A Baseline Study, International Institute for Environment and Development(IIED), World Bank.

GTZ(2007), The CSR Navigator: Public Politicies in Africa, the Americas, Asia and Europe, Bertelsmannstiftung.

Hopkins, Michael(2008), Corporate and Stakeholder Responsibility: Theory and Practice, Fifth Annual Forum on Business Ethics and Corporate Social Responsibility in a Global Economy, Milan, 22th-23th May 2008.

Korachun, D., Bhattacharya, C. B. and Swain, S.(2011), 'When and How Does Corproate Social Responsibility Encourage Customer Orientation?', Working Paper.

Kotler, Philip and Lee, Nancy(2004), Corporate Social Responsibility: Doing the Most Good for Your Company and Your Cause, Wiley.

Pava, MI., Krausz, J.(1996), 'Corporate Social Responsibility and Financial Performance: the paradox of social cost', Westport, Quorum Books.

Poter, Michael E. and Kramer, Mark R.(2006),'Strategy \& Society : The Link Between Competitive Advantage and Corporate Social Responsibility', Harvard Business Review, vol.84, no.12.

Stanwick, P. A. and Stanwick, S. D.(1998), 'The relationship between corporate social performance and organizational size financial performance and environmental performance: an empirical examination', Journal of Business Ethics, vol. 17.

UN Global Compact(2010), The Role of Governaments in Promoting Corporate Responsibility and Private Sector Engagement in Development, Bertelsmannstiftung.

Ward, Halina(2004), Public Sector Roles in Strengthening Corporate Social Responsibility: Taking Stock, World Bank.

World Bank(2005), Social Accountability in the Public Sector: A Conceptual Discussion and Learning Module, Working Paper, World Bank Institute. 